\title{
Assessment of learning difficulties in the category of children with dyslexia
}

\author{
Trubus Raharjo ${ }^{1}$, Supra Wimbarti ${ }^{2}$ \\ ${ }^{1}$ Program Doktor Ilmu Psikologi Universitas Gadjah Mada, Indonesia \\ ${ }^{2}$ Fakultas Psikologi Universitas Gadjah Mada, Indonesia
}

\section{Article Info \\ Article history:}

Received Apr 20th, 2020

Revised Mei 26th, 2020

Accepted Jun 2nd, 2020

\section{Keyword:}

Dyslexia

Reading

Writing

Diagnosis

\begin{abstract}
This study is aimed to assess the diagnostic criteria for children with dyslexia. The diagnostic criteria are based on behavioral symptoms that appear in children with difficulty in reading and writing. The measurement of criteria of dyslexia is based on the criteria found in the specific learning difficulties category in DSM-5. Measurements were made of children who were considered to have learning difficulties as indicated by the inability and poor learning outcomes. Measurements were by testing the ability to read and write. Research used a qualitative approach with a case study method to obtain a description of the results. Research subjects were conducted on 65 elementary school students who had indications of learning difficulties. The results on the ability to read and write obtained as many as 28 students who were indicated to have criteria of dyslexia. Materials testing with aspects of phonological awareness and orthographic aspects. The next measurement is done by conducting an intelligence test using WISC III. Combining the results of measurements of reading and writing abilities and the results of intelligence tests are used to diagnose children with dyslexia, based on the criteria for indications of dyslexia taken from DSM-5. The results category on children with dyslexia can be diagnosed using one or more of the categories available on DSM-5
\end{abstract}

(C) 2020 The Authors. Published by Indonesian Institute for Counseling, Education and Therapy (IICET). This is an open access article under the CC BY license (https://creativecommons.org/licenses/by/4.0/)

\section{Corresponding Author:}

Trubus Raharjo,

Program Doktor Ilmu Psikologi, Universitas Gadjah Mada

Email: trubuspsi@gmail.com

\section{Pendahuluan}

Disleksia merupakan bentuk gangguan belajar spesifik yang merujuk pada ketidakmampuan belajar yang berbeda dengan pengertian ketidakmampuan belajar secara umum, dan merupakan kategori kesulitan belajar berkaitan dengan kelemahan dalam mendengar, membaca, menulis dan matematika (Lyon, Shaywitz dan Shaywitz, 2003). The International Dyslexia Association (Martinez, Ramos, Callaway dan Miller, 2014) disleksia sebagai kesulitan belajar spesifik berasal faktor neurologis, ditandai dengan kesulitan mengenali kata dan kemampuan yang buruk dalam merekognisi kata, mengeja serta kemampuan membedakan huruf dan kata. Adapun Organisasi Kesehatan Dunia (Beech, 2013) disleksia merupakan gangguan spesifik dalam membaca tetapi tidak terkait dengan gangguan mental dan masalah ketajaman visual. Shaywitz (2003) memprediksi penderita disleksia mencapai antara 5\% sampai 17\% terjadi pada anak-anak usia sekolah.

Penelitian pada anak dengan disleksia berdasarkan defisit membaca dan mengeja ditemukan bahwa gangguan fonologi, gangguan visual dan auditori menunjukkan $94 \%$ dialami oleh anak-anak dengan disleksia pada tingkat sekolah dasar (Jan Le, dkk, 2011). Penting untuk melihat kesulitan belajar pada anak disleksia dari sebab-sebab kelemahan dalam membaca dan menulis yang serius (Serrano \& Defior, 2008). Lebih lanjut Serrano \& Defior (2008) disleksia sebagai permasalahan yang terdapat pada anak-anak dengan 
kapasitas inteligensi yang normal. Gabrieli (2009) bahwa disleksia sering diidentikkan dengan perbedaan antara skor rata-rata atau di atas rata-rata dari inteligensi secara umum dan tes kemampuan membaca di bawah standar. Ferrer, dkk (2010) mengindikasikan adanya hubungan timbal balik antara kemampuan membaca dan IQ untuk melihat perbandingan dalam perkembangan membaca. Lebih lanjut Ferrer, dkk (2010) bahwa kesulitan dalam membaca akan menghambat anak-anak disleksia untuk menerapkan kemampuan membaca di kelas dan menghambat anak dalam mempraktekkan kemampuan membaca secara mandiri dan komprehensif pada tahun berikutnya.

Dalam pandangan teoritis ada tiga kerangka besar untuk mengidentifikasi disleksia, yaitu 1) adanya kelemahan dalam fonologi, 2) kelemahan fungsi magnoseluler dan 3) kerusakan pada fungsi otak (Fawcett \& Nicolson, 2007). Penelitian yang dilakukan oleh Gooch, Snowling, dan Hulme (2011), terhadap siswa yang mengalami disleksia dan siswa yang tidak mengalami disleksia, diperoleh hasil bahwa siswa yang memiliki gangguan disleksia mengalami gangguan baik kelancaran maupun bahasa terkait fonologi. Ada beberapa indikator yang dapat digunakan untuk mengetahui disleksia pada usia awal (Riddick, 2003), yaitu kesulitan berkata dengan kalimat yang panjang, kesulitan dalam belajar, kesulitan menyebutkan bulan dalam satu tahun, kesulitan menyebutkan huruf yang hampir mirip seperti b, d dan p. Shaywitz (2003), mengemukakan tes membaca sebagai cara untuk mengetahui kelancaran membaca. salah satunya untuk melihat ketepatan dalam pengucapan huruf dan kata.

Seorang siswa dengan disleksia biasanya menunjukkan beberapa gangguan dalam pembelajarannya (Olson, Keenan, Byrne dan Samuelsson, 2014). Lebih lanjut Olson, dkk (2014) mengemukakan beberapa perilaku yang dapat ditunjukkan dengan resiko disleksia pada anak SD dengan resiko disleksia antara lain: 1) Kesulitan merangkai kata-kata menjadi kalimat yang benar, 2) Kesulitan mengingat nama huruf dan mengingat huruf yang sesuai, 3) Kesulitan menguraikan kata-kata, 4) Kesulitan mengeja kata-kata sesuai suara (secara fonetis) atau mengingat urutan huruf dalam kata-kata yang sangat sering didengar, 5) Kesulitan mengingat suara yang benar untuk huruf dan pola huruf dalam membaca, 6) Kesulitan mengucapkan suku kata pada kata yang sesuai dan menghilangkan huruf dengan kata-kata untuk ejaan (mis., "setelah" dieja "seletah"), 7) Kesulitan dengan ekspresi tertulis, 8) Kesulitan membaca memahami bacaan. Asosiasi disleksia Inggris (Beech, 2013), menyatakan beberapa indikasi anak yang mengalami disleksia antara lain 1) mengalami kesulitan dalam membedakan bunyi, 2) kurang perhatian, 3) kurang dapat membedakan suara, 4) mempunyai riwayat perkembangan lambat bicara, 5) kesulitan dalam menangkap, menendang dan melempar bola, 6) kesulitan melompat dan melewati rintangan, 7) mengalami kesulitan menbedakan arah kanan atau kiri.

Penelitian terhadap anak dengan disleksia berdasarkan defisit membaca dan mengeja menemukan bahwa gangguan pengetahuan metafonologi, morfologi, gangguan visual dan auditori menunjukkan $94 \%$ dialami oleh anak-anak disleksia pada tingkat sekolah dasar (Jan Le, dkk. 2011). Pembahasan tentang kemampuan kognitif yang terjadi karena gangguan fonologi, gangguan visual dan gangguan auditori adalah faktor penting untuk melakukan diagnosis terhadap penderita disleksia (Tamboer, Vorst, dan Oort, 2016). Adapun indikasi gangguan pada anak disleksia juga dikemukakan Asosiasi disleksia Inggris (Reid, 2011) beberapa indikasi anak yang mengalami disleksia antara lain 1) mengalami kesulitan dalam membedakan bunyi, 2) kurang perhatian, 3) kurang dapat membedakan suara, 4) mempunyai riwayat perkembangan lambat bicara.

Penggunaan alat tes disleksia berbahasa asing masih menjadi kendala untuk mendeteksi anak dengan disleksia yang tidak sama antara satu negara dengan negara lain, kendala disebabkan karena standar bahasa yang berbeda (Smythe, Everatt dan Salter, 2004). Disleksia bersifat individu dan setiap individu disleksia berbeda pada setiap negara, budaya dan konteks pendidikan. Perbedaan karakteristik dari penderita disleksia dari berbagai negara disesuaikan dengan bahasa di negara tersebut, sehingga tidak ada satu tes pengukuran yang sesuai terkait perbedaan bahasa (Smythe, Everatt dan Salter, 2004).

Adapun karakteristik bahasa Indonesia mempunyai struktur bahasa tersendiri, sebagaimana Winskel \& Widjaja (2007) mengemukakan bahwa susunan bahasa Indonesia yang diucapkan sehari-hari sering menggunakan bentuk yang tidak bercampur. Anak-anak Indonesia harus bisa membaca dan memahami kata imbuhan tersebut lebih dulu sehingga dapat memahami arti kata tersebut. Penelitian pengukuran kemampuan membaca di Indonesia dilakukan Jap, Borleffs dan Maassen (2017), yang menyusun tes membaca untuk standar Indonesia. Penelitian ini dilakukan sebagai tes skrening membaca yang dikenakan pada anak kelas satu pada salah satu sekolah dasar di Indonesia. Penelitian ini hanya dimaksudkan untuk menghasilkan standar tes kemampuan membaca pada siswa pembaca pemula.

Kriteria yang digunakan untuk mendiagnosis anak dengan disleksia pada pengukuran ini menggunakan kriteria kesulitan belajar spesifik yang ada pada Diagnostic and Statistical Manual of Mental Disorder 
(DSM-5), Pada spesifikasi secara khusus juga disebutkan yang termasuk kriteria dalam kesulitan membaca terkait dengan ketepatan membaca kata, rata-rata kelancaran membaca, membaca dengan baik, adapun spesifikasi dengan kesulitan ekpresi tulisan terkait dengan ketepatan mengeja, ketepatan menulis tata kalimat (APA, 2013).

\section{Metode}

Penelitian ini menggunakan pendekatan kualitatif dan metode yang digunakan adalah metode studi kasus. Penelitian kualitatif bersifat deskriptif dan cenderung menggunakan analisis dengan pendekatan induktif. Strauss dan Corbin (2003) menyatakan metode kualitatif sebagai prosedur penelitian yang menghasilkan data deskriptif berupa perilaku yang diamati dan kata-kata tertulis atau lisan dari subjek penelitian.

Subyek penelitian sebanyak 65 siswa (40 laki-laki dan 25 perempuan), partisipan adalah siswa sekolah dasar antara kelas 2 sampai kelas 5 yang dilakukan pada beberapa SD, dengan usia rata-rata 9 tahun. Seluruh partisipan diindikasikan mengalami kesulitan belajar berdasarkan hasil prestasi akademik yang dianggap kurang oleh guru kelas, setelah dilakukan pengukuran kemampuan membaca dan menulis serta tes inteligensi, didapatkan sebanyak 28 siswa yang diindikasikan mengalami disleksia, kemudian dilakukan penyesuaian kriteria disleksia dengan melihat kategori disleksia pada DSM-5.

Pengukuran awal berdasarkan aspek fonologi dengan memberikan tugas terhadap kemampuan mengeja dan membaca. Pengukuran menggunakan deret hurut serta membaca kata dan kalimat. Partisipan diminta untuk membaca 20 deret huruf yang ditunjukkan. Kemampuan membaca dilakukan dengan memberikan kalimat yang terdiri dari 20 kata pada suatu bacaan yang ditunjuk secara acak oleh tester dari berbagai jenis huruf. Pada tes kemampuan ortografi dilakukan dengan memberikan tes menggunakan deret hurut sebanyak 20 deret dan menulis kalimat dalam satu paragraf.

Langkah awal dilakukan uji terhadap kemampuan fonologi dan orthografi terhadap 65 siswa, dilanjtkan dengan melakukan tes IQ, dilakukan terhadap 28 siswa. Pengukuran inteligensi menggunakan Tes Wechsler Intelligence Scale for Children (WISC-III), untuk mengetahui apakah inteligensi siswa yang diindikasikan mengalami disleksia mempunyai inteligensi di bawah normal, normal atau bahkan superior. Memasukkan hasil tes kemampuan fonologi, kemampuan orthografi serta hasil tes inlelegensi dalam kriteria diagnostik DSM-5. Berdasarkan kriteria diagnostik pada DSM-5 untuk menentukan kriteria anak dengan kesulitan belajar spesifik kategori disleksia pada ada 4 kriteria diagnositik.

Penentuan kriteria diagnostik pada anak disleksia dilakukan dengan menyesuaikan kriteria yang terdapat pada Diacnostic and Statistical Manual of Mental Disorder (DSM-5), dinyatakan bahwa kriteria disleksia mengacu pada kesulitan belajar spesifik yaitu kesulitan belajar dan penggunaan ketrampilan akademik, antara lain berkaitan dengan : 1) Ketidaktepatan atau lambat atau tidak ada upaya dalam membaca (misalnya ketidaktepatan saat membaca huruf atau terlalu lambat dan ragu-ragu, sering menebak kata-kata, memiliki kesulitan terdengar kata-kata). 2) Kesulitan memahami makna dari apa yang dibaca (misalnya, dapat membaca teks secara akurat tetapi tidak memahami urutan, hubungan, kesimpulan, atau makna yang lebih dalam dari apa yang dibaca). 3) Kesulitan dengan ejaan (misalnya, dapat menambahkan, menghilangkan, atau vokal pengganti atau konsonan). 4) Kesulitan dengan ekspresi tertulis (misalnya, membuat kesalahan tata bahasa atau kesalahan tanda baca dalam kalimat; ide dalam ekspresi tertulis tidak memiliki kejelasan). Kategori lain dalam penentuan kriteria diagnostik dalam menentukan diagnosis terhadap anak dengan gangguan disleksia yaitu kemampuan intelektual pada anak kesulitan belajar spesifik ditunjukkan dengan inteligensi (IQ) kategori level normal.

\section{Hasil dan Pembahasan}

Berdasarkan hasil pengukuran terhadap 65 siswa diperoleh data awal bahwa ada 37 siswa yang dianggap tidak mempunyai kategori kesulitan belajar spesifik, hal ini ditunjukkan dengan tidak ada kesalahan pada semua tes yang diberikan baik dalam mengeja, membaca maupun menulis dan terhadap 28 anak yang diindikasikan mengalami disleksia, secara umum mempunyai inteligensi antara 85 - 112 (skala WISC). Pengujian terhadap kecepatan membaca diukur berdasarkan kemampuan rata-rata seluruh partisipan dalam membaca 100 kata dengan waktu 1 menit dan diperoleh rata-rata kemampuan anak sebanyak 40 kata.

Penentuan klasifikasi kesulitan belajar spesifik pada kategori disleksia dilakukan dengan panduan yang terdapat pada DSM-5, digunakan sebagai dasar dalam menentukan kriteria diagnosis terhadap anak dengan 
disleksia menggunakan kriteria diagnostik gangguan belajar spesifik (Specific Learning Disorder) yang terdapat dalam DSM 5, berdasarkan keriteria kesulitan belajar dan penggunaan keterampilan akademik pada kategori pertama: Ketidaktepatan atau lambat atau tidak ada upaya dalam membaca (misalnya ketidaktepatan saat membaca huruf atau terlalu lambat dan ragu-ragu, sering menebak kata-kata, memiliki kesulitan mendengar kata-kata). Pengukuran kecepatan rata-rata anak normal dalam membaca kata dalam satu menit minimal 40 kata. Diperoleh hasil pengukuran kemampuan kecepatan membaca di bawah 40 kata terdapat 9 anak yang memiliki kriteria lambat dalam membaca atau kemampuan membaca kurang lancar serta masih terbata-bata.

Pada kategori kedua: Kesulitan memahami makna dari apa yang dibaca (misalnya, dapat membaca teks secara akurat tetapi tidak memahami urutan, hubungan, kesimpulan, atau makna yang lebih dalam dari apa yang dibaca). Hasil pengukuran kemampuan membaca menunjukkan ada 2 partisipan yang termasuk dalam kriteria dapat membaca namun pada saat membaca bacaan yang dibaca terdengar tidak jelas sehingga terlihat bahwa anak tidak memahami makna lebih dalam dari apa yang dibaca.

Berdasarkan kategori ketiga: Kesulitan dengan ejaan (misalnya, dapat menambahkan, menghilangkan, atau vokal pengganti atau konsonan). Hasil observasi kemampuan membaca, ada 8 subyek yang mempunyai kemampuan membaca namun ada beberapa huruf yang tidak dibaca atau hilang. Permasalahan yang ada pada partisipan saat mengeja adalah 1) Mengeja tidak lancar, 2) Saat mengeja atau membaca kata ada beberapa huruf yang tidak di baca bahkan ada anak yang sama sekali belum bisa membaca. Diperoleh hasil observasi kemampuan membaca, 1) ada beberapa huruf yang tidak dibaca atau hilang, 2) Beberapa kata yang salah pada saat membaca dalam kategori menghilangkan huruf pada kata seperti "hidup" dibaca "hidu", "makan" dibaca "maka", "dengan" dibaca "degan".

Pada kategori keempat Kesulitan dengan ekspresi tulisan (misalnya, membuat kesalahan tata bahasa atau kesalahan tanda baca dalam kalimat; ide dalam ekspresi tertulis tidak memiliki kejelasan) dan kategori inteligensi. Diperoleh hasil pengujian kemampuan menulis, ada 18 partisipan dengan kriteria mengalami kesulitan dalam menulis dengan tulisan yang tidak bisa dibaca dan kesalahan tata bahasa. Berdasarkan hasil pengujian kemampuan menulis, ada 18 partisipan dengan kriteria mengalami kesulitan dalam menulis dengan tulisan yang tidak bisa dibaca serta kesalahan tata bahasa. Kesalahan pada penulisan deret terjadi pada huruf $\mathrm{b}$ menjadi $\mathrm{d}, \mathrm{n}$ menjadi $\mathrm{u}$, $\mathrm{q}$ ditulis $\mathrm{k}$, $\mathrm{q}$ ditulis $\mathrm{p}$. Beberapa kategori kesalahan pada saat menulis terlihat pada hasil identifikasi sebagai berikut: 1) Tulisan terbaca tetapi ada beberapa huruf dalam kata yang tidak ditulis, seperti "rumah" hanya ditulis "ruma", 2) Penulisan huruf besar di tengah kata, seperti "memBangun", 3) Tulisan sulit dibaca karena banyak huruf yang bentuknya tidak beraturan sebagaimana bentuk huruf huruf pada umumnya, 4) Pada saat menulis sering salah sehingga anak selalu menghapus kata yang ditulis, 5) Antar kata tidak ada jeda sehingga tulisan terlihat tidak berspasi. Bentuk tulisan yang mempunyai kesalahan pada kategori ini dapat dilihat pada gambar 1 dan gambar 2:

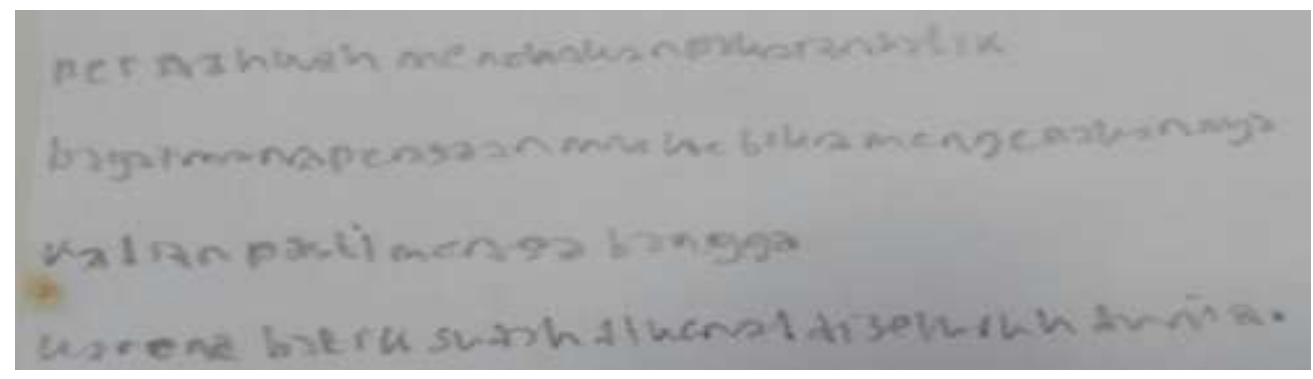

Gambar1: Contoh tulisan anak dengan kriteria disleksia

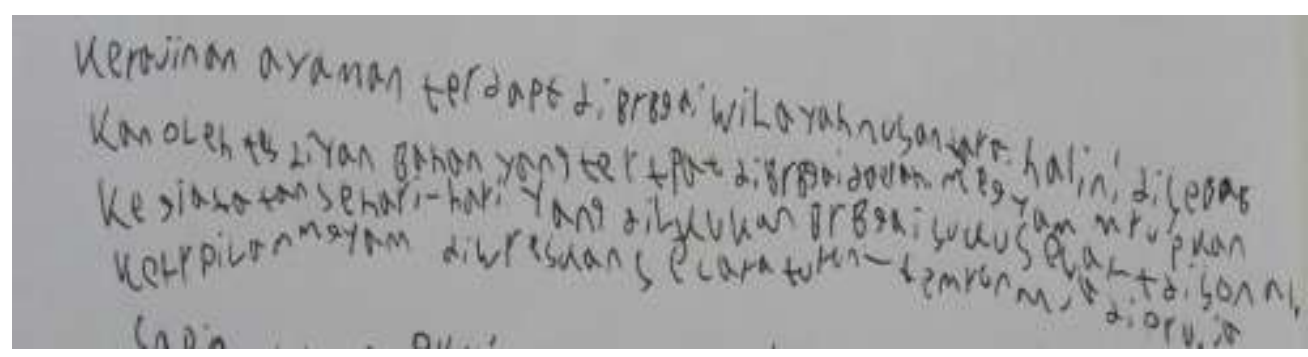

Gambar 2: Contoh tulisan anak dengan kriteria disleksia 
Secara keseluruhan hasil kategori pada DSM-5 merupakan hasil sesuai kategori, namun sesungguhnya secara keseluruhan pada partisipan dapat terjadi gabungan dari 2 atau bahkan lebih kriteria pada DSM-5. Data keseluruhan sesuai kategori kesulitan belajar yang merupakan bentuk kategori disleksia, diperoleh hasil sebanyak 2 partisipan yang masuk pada kategori pertama (lambat dalam mengeja), ada 1 partisipan yang masuk pada kategori kedua (pemahaman), ada 1 partisipan yang masuk pada kategori ketiga, adapun partisipan yang masuk kategori ketiga dan keempat ada 11 partisipan (membaca dan menulis), sedangkan yang hanya masuk kategori keempat sebanyak 12 partisipan (menulis). Secara akumulasi dapat dilihat pada gambar 3 .

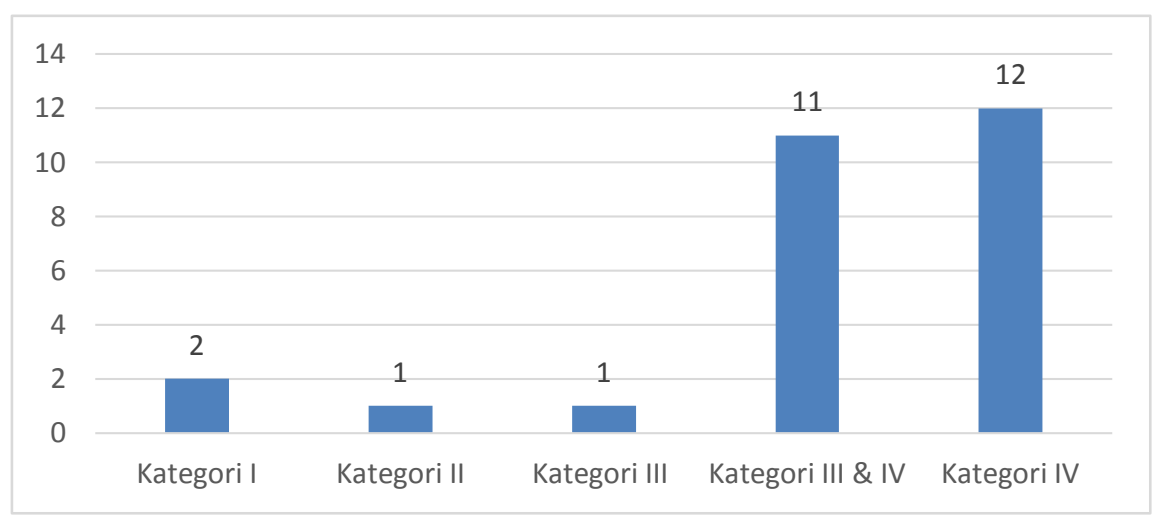

Gambar 3. Pengelompokan kategori disleksia

Hasil temuan menunjukkan beberapa kriteria spesifikasi kesulitan belajar pada anak baik pada kemampuan membaca maupun menulis, Awada dan Plana (2018) mengemukakan bahwa siswa dengan kesulitan membaca biasanya memiliki kesulitan serius dalam memahami pola teks dan tidak mampu mengenali struktur teks, yang menghambat pengambilan informasi konten. Beberapa sudut pandang teoritis berkaitan dengan faktor visual dan auditori pada anak disleksia dikemukakan oleh Stein (Reid, 2011), pertama mencakup proses pengenalan visual umum dan dengan sudut pandang sejarah defisit visual sebagai penyebab disleksia. Mather \& Wendling (2012) mengemukakan bahwa sangat penting anak-anak dengan disleksia menerima instruksi spesifik dalam kesadaran fonologis karena jenis pengajaran ini membuat perbedaan dalam membaca dan mengeja. Hubungan antara kesadaran fonologis dan kemampuan membaca bersifat timbal balik dan dua arah: ketika kesadaran fonologis berkembang, kemampuan membaca meningkat dan ketika kemampuan membaca meningkat maka kesadaran fonologis pada anak pun lebih baik.

Berdasarkan pengukuran juga diperoleh hasil bahwa bahwa ketidakmampuan anak dengan disleksia berhubungan erat dengan kesadaran fonologi, hal ini menunjukkan bahwa membaca berkaitan erat dengan kesadaran fonologi pada anak. Studi tentang proses ejaan pada anak-anak disleksia mendapatkan perhatian yang meningkat karena kesulitan dalam pemrosesan fonologis dan dalam perolehan kode alfabet dapat mendiskripsikan pola perkembangan ejaan yang berbeda dari anak-anak yang tidak mengalami disleksia. Berdasarkan hasil pengamatan terhadap perubahan dalam jenis kesalahan ejaan, dari kesalahan asumsi kegagalan secara fonologis di mana kesalahan mengeja mengubah pengucapan kata, menjadi kesalahan yang memang mempengaruhi kesadaran fonologis (Suárez-Coalla, dkk. 2016). Hasil penelitian sama dengan yang ditemukan oleh Suárez-Coalla, dkk (2016) mengenai hubungan antara pemrosesan fonologis dengan membaca ejaan dalam perkembangan anak disleksia.

Tes kemampuan mengeja, membaca dan menulis mencerminkan bentuk tes terkait diagnosis terhadap anak disleksia. Berdasarkan konsep disleksia sebagai kesulitan terhadap kemampuan dasar dalam membaca serta diinterpretasikan sebagai lemahnya prestasi akademik (McArthur, 2011). Tentunya, tes prestasi belajar (matematika sebagai contoh), bahasa, menulis atau ingatan merupakan bagian dari evaluasi keseluruhan terhadap siswa dengan gangguan disleksia (Swanson, Harris \& Graham, 2006). Identifikasi dan intervensi awal sangat penting untuk meminimalkan dampak pada ketidakmampuan membaca pada anak dan perlu disadari bahwa anak sedang berjuang dengan keterampilan bahasa tertulis, berapa pun usianya, maka hasil analisis terhadap anak sangat membantu saat memberikan konseling membaca (Franklin, 2018)

Temuan lain menunjukkan bahwa anak yang mengalami gangguan belajar spesifik tidak terkait secara langsung dengan inteligensi (IQ), Shaywitz (2003), mengemukakan beberapa gangguan utama yang dialami 
oleh anak disleksia adalah 1) Lemahnya kemampuan fonologi (phonological awarness) merupakan faktor utama bagi anak disleksia disamping lemahnya kemampuan membaca. Inteligensi (IQ) dalam hal ini justru tidak berpengaruh bahkan pada mereka yang mempunyai IQ di atas rata-rata bahkan superior. 2) Kesulitan belajar dalam bahasa merupakan kekurangan dalam semua aspek bahasa termasuk dalam pendengaran. Pengukuran melalui inteligensi verbal sangat signifikan untuk melihat kekurangan dalam bahasa. 3) Kesulitan belajar membaca karena terjadinya trauma pada otak disebabkan adanya benturan, tumor atau stoke pada otak akan mempengaruhi sistem kemampuan otak dalam membaca. Lebih lanjut Shaywitz (2003) mengemukakan bahwa anak yang mempunyai IQ rata-rata atau di atas rata rata diharapkan mempunyai kemampuan membaca yang baik, namun pada anak disleksia ada kesenjangan antara IQ dengan kemampuan membaca.

Diperlukan bimbingan kepada anak dengan disleksia, sebagimana dikemukakan Widyorini dan van Tiel (2017), bahwa remedial teaching perlu diberikan kepada siswa yang secara spesifik mempunyai gangguan belajar disleksia, dilakukan oleh guru yang mempunyai pendidikan khusus atau psikologi pendidikan, dengan penanganan menggunakan metode khusus atau dilakukan oleh konselor yang ahli dalam bidang pendidikan.

\section{Kesimpulan}

Sangat penting mengetahui dan mengidentifikasi kesulitan belajar pada anak disleksia, melalui observasi dan pengukuran yang baik dilakukan untuk mengumpulkan data dan melihat karakteristik yang spesifik dari bentuk kesulitan belajar pada anak. Dimaksudkan untuk menemukan gambaran cara pengajaran yang tepat sesuai dengan karakteristik kesulitan belajar pada anak. Berdasarkan hasil pengukuran terhadap anak dengan kategori disleksia menggunakan DSM-5 terlihat bahwa kategori untuk mendiagnosis anak mengalami disleksia dapat ditentukan menggunakan salah satu kategori yang ada pada DSM-5, sebagaimana disebutkan pada DSM-5 bahwa ahli yang berkompeten menentukan diagnosis disleksia pada anak dapat berpedoman pada gejala-gejala yang nampak pada DSM-5 yang muncul sebagai perilaku pada anak berkesulitan belajar pada salah satu kategori. Hasil pengukuran juga memperlihatkan bahwa anak dengan kategori disleksia dapat mengalami kegagalan pada salah satu kategori maupun beberapa kategori. Kategori pada DSM-5 juga menunjukkan bahwa anak dengan disleksia tidak terkait langsung dengan inteligensi (IQ), di mana anak dengan disleksia cenderung mempunyai intelegensi normal, hal ini menunjukkan bahwa anak dengan disleksia mempunyai gangguan belajar spesifik bukan gangguan inteligensi. Mengetahui bentuk kegagalan pada anak berkesulitan belajar kategori disleksia merupakan hal yang sangat penting untuk membantu anak mengatasi kegagalan akademik, sehingga dapat diberikan perlakuan yang tepat serta intervensi yang sesuai dengan kegagalan yang dialami anak dengan disleksia. Identifikasi dan intervensi sangat penting untuk meminimalkan dampak pada ketidakmampuan membaca dan menulis pada anak. Rekomendasi terhadap praktisi pendidikan terkait kegagalan akademik pada anak disleksia diharapkan dapat membantu anak memberikan pendampingan terhadap masalah dalam membaca atau menulis. Hasil analisis yang tepat terhadap anak sangat membantu saat memberikan perlakuan dan konseling yang diperlukan saat anak sedang belajar.

\section{Referensi}

Awada, G., \& Plana, M. G. C. (2018). Multiple strategies approach and EFL reading comprehension of learners with dyslexia: Teachers' perceptions. International Journal of Instruction, 11(3), 463-476. https://doi.org/10.12973/iji.2018.11332a

Beech, J. (2013). The Little Book of Dyslexia. Wales-British: Independent Thinking Press.

Fawcett, A. J., \& Nicolson, R. I. (2007). Dyslexia, learning, and pedagogical neuroscience. Developmental Medicine and Child Neurology, 49(4), 306-311. https://doi.org/10.1111/j.1469-8749.2007.00306.x

Ferrer, E., Shaywitz, B. A., Holahan, J. M., Marchione, K., \& Shaywitz, S. E. (2010). Uncoupling of reading and iq over time: Empirical evidence for a definition of dyslexia. Psychological Science, 21(1), 93-101. https://doi.org/10.1177/0956797609354084

Franklin, D. (2018). Helping your child with language-based learning disabilities. New Harbinger Publications, Inc. 5674 Shattuck Avenue Oakland; Canada

Gabrieli, J.D.E. (2009). Dyslexia: A New Synergy between Education and Cognitive Neuroscience. Science, New Series, Vol. 325, No. pp. 280-283

http://www.jstor.org/stable/20536638 
Gooch, D., Snowling, M., \& Hulme, C. (2011). Time perception, phonological skills and executive function in children with dyslexia and / or ADHD symptoms. 2, 195-203. https://doi.org/10.1111/j.14697610.2010.02312.x

Jan, G. Le, Bouquin-jeannès, R. Le, Costet, N., \& Trolès, N. (2011). Multivariate predictive model for dyslexia diagnosis. 1-20. https://doi.org/10.1007/s11881-010-0038-5

Jap, B. A. J., Borleffs, E., \& Maassen, B. A. M. (2017). Towards identifying dyslexia in Standard Indonesian: the development of a reading assessment battery. Reading and Writing, 30(8), 1729-1751. https://doi.org/10.1007/s11145-017-9748-y

Lyon, G.R., Shaywitz, S.E., Shaywitz, B.A., (2003). Part 1. Defining dyslexia, comorbidity, teachers' knowledge of language and reading. A definition of dyslexia. Annal Dyslexia.53, 1-14. https://doi.org/10.1007/s11881-003-0001-9

Mather,N., \& Wendling, B. (2012). Essentials of Dyslexia Assessment and Intervention. John Wiley \& Sons,

Martinez, M., Ramos, L., Callaway, K., Miller, K. (2014). The Dyslexia Handbook. Procedures Concerning Dyslexia and Related Disorders. Texas Education Agency. Austin, Texas

McArthur, G. M. (2011). Living with dyslexia. In Australian Journal of Learning Difficulties (Vol. 16, Issue 2). https://doi.org/10.1080/19404158.2011.605748

Olson, R. K., Keenan, J. M., Byrne, B., \& Samuelsson, S. (2014). Why do children differ in their development of reading and related skills? Scientific Studies of Reading, 18 (1), 38-54

Reid, G. (2011). Dyslexia (Special Education Need). Continuum International Publishing Group. New York. https: //doi.org/10.1111/j.1469-7610.2010.02312.x

Riddick, B. (2003). Live With Dyslexia. The Taylor and Francis E-Library; USA

Serrano, F and Defior, S. (2008). Dyslexia speed problems in a transparent orthography. Annals of Dyslexia, Vol. 58, No. 1 pp. 81-95

Smythe, I., Everatt, J., \& Salter, R. (2005). The International Book of Dyslexia: A Guide to Practice and Resources. https://books.google.com/books?id=7IR65J6NfeQC\&pgis=1

Shaywitz, S.E. (2003). Overcoming dyslexia: A new and complete science-based program for reading problems at any level. New York: Alfred A. Knopf.

Swanson, H.L., Harris, K.R and Graham, S. (2006). Handbook of Learning Disabilities. New York. NY; Guilford Press. (pp 514 -531).

Strauss, A dan Corbin, J. (2003). Dasar-dasar Penelitian Kualitatif. Yogyakarta: Pustaka Pelajar

Suárez-Coalla, P., Villanueva, N., González-Pumariega, S., \& González-Nosti, M. (2016). Spelling difficulties in Spanish-speaking children with dyslexia / Dificultades de escritura en niños españoles con dislexia. Infancia y Aprendizaje, 39(2), 275-311. https://doi.org/10.1080/02103702.2015.1132979

Tamboer, P., Vorst, H. C. M., \& Oort, F. J. (2016). Five Describing Factors of Dyslexia. Journal of Learning Disabilities, 49(5), 466-483. https://doi.org/10.1177/0022219414558123

Widyorini, E. dan van Tiel, J.M. (2017). Disleksia: Deteksi, Diagnosis, Penanganan di Sekolah dan di Rumah. Prenada: Jakarta.

Winskel, H., \& Widjaja, V. (2007). Phonological awareness, letter knowledge, and literacy development in Indonesian beginner readers and spellers. Applied Psycholinguistics, 28(1), $23-45$. https://doi.org/10.1017/S0142716407070026 